\title{
Epithelial Cell Aggregation and Separation
}

National Cancer Institute

\section{Source}

National Cancer Institute. Epithelial Cell Aggregation and Separation. NCI Thesaurus.

Code C19825.

A method for rapidly obtaining near-pure aggregates of epithelial cell populations.

Smears are prepared, rapidly fixed in methanol and stained. Microscopic examination permits precise identification of epithelial cell aggregates for separation by laser capture microdissection. 